\title{
Effect of Agency Costs on Executive Compensation in South African Commercial Banks
}

\author{
Odunayo Magret Olarewaju*, Stephen Oseko Migiro, Mabutho Sibanda \\ University of KwaZulu- Natal, Westville Campus, Durban, South Africa \\ olarewaju_odunayo@yahoo.com*, migiro@ukzn.ac.za,sibandam@ukzn.ac.za
}

\begin{abstract}
This study examines the roles of agency cost (monitoring and bonding cost) on compensation of managers with a view from the managerial-power approach to agency cost. We modelled managers' compensation and agency cost of banks to emphasise the potential influence of agency cost on managers' compensation. A Panel Generalised Least Square model was estimated on four largely-controlled commercial banks in South Africa over the period 2010-2015. The result shows that shareholders' fund, management share option, monitoring and bonding cost were strongly significant in explaining the managers' compensation in the banks. Therefore, in the South African banking sector, compensation of managers should be based on their managerial power and not only on the principle of optimal-contracting. It is recommended, among others, that monitoring and bonding costs in the South African banks should be re-emphasised and strictly committed to. This should be so because there are direct effects of these costs on managers' compensation which might be the reason for the persistent agency problem in the banks.
\end{abstract}

Keywords: Managers' option, Monitoring cost, Bonding cost, Executive compensation, Managerial-Power Approach

\section{Introduction}

Financial intermediaries are unique institutions in all economies that are operating a free-market system. For such institutions to be able to act in their full capacity as intermediaries; they need to form agency relationships. The banking sector as a major financial intermediary is not excluded from this type of relationship as all its activities are run in view of the agency relationship in which the parties involved are the owners (shareholders) and the managers (agents). Jensen's theory of firm defined agency relationship as a contract between two people known as principal and agent, in which the principal engages the agent to render some services on its behalf by delegating a fractional decision-making power to the agent. It is expected that the agent should at all costs render a steward account to the principal per time, but due to the fact that both principal and agent are 'utility-maximisers' (Collier \& Agyei-Ampomah, 2006), it is rational to believe that the agent will be sub-optimal and will not be acting solely in the principal's interest. Agency problems emanate in the banking sector from the conflicting interests between the shareholders and the agents due to, for example, information asymmetries and uncertainties, failure to allow managers to accept projects that will yield positive net present value, discrepancies in the perquisites either financial or nonfinancial paid to the managers, responsibility allocation, management and collective production (Kantarelis, 2007). Therefore, agency costs can be seen as the loss in value for shareholders caused by interest divergences between the owners and the managers. In order to limit the divergence in the interests of these parties, owners have accepted the need to incur monitoring costs utilising diverse ways so as to woo the interest of the managers to maximise their wealth by strictly following up their activities. Also the managers admits to expend some resources known as bonding costs in order to show their interest in the betterment of the owners, maximisation of their wealth, and pledge to compensate the owners if they defaults being optimal to the ultimate goal of the firm. Nevertheless, for banks to ensure that managers maximise shareholders' wealth, it is necessary for the shareholders to incur the costs of monitoring and for managers also to incur bonding costs. Generally, when a firm is at zero agency cost, there is doubt that manager' make optimal decisions in the sole interest of the shareholders; hence, agency costs are inevitable (Ang et al., 2000).

According to Masulis and Trueman (1988), severe conflict of interests between managers and owners always exists despite the full right of shareholders to participate in, and exercise voting rights during annual general meetings and in the appointing and dismissing of managers, appointing auditors, and accepting or rejecting annual reports and accounts. These conflicts arise due to the following major reasons and consequently cause agency costs for firms. Firstly, managers prefer less work with higher levels of consumption as they have the assurance that their remuneration with their quota in the value of the company's shares will not decrease; secondly, managers, due to the possibility of bankruptcy and loss of job opportunities, invest the companies' 
capital in less risky projects that will yield lower financial leverage, so as to avoid managerial capital and portfolios losses; thirdly, managers prefer quick returns on investment that emanate from short-term investment; and lastly, managers always take actions and decisions that will avoid reductions in the level of employment so that the lines of reporting they maintain will not change. Due to the fact that the banking sector cannot do without the activities of these managers, it is necessary to ascertain for the factors that can reduce compensation and still increase the value of the firm. Murphy (1985) affirms that managers' remuneration is correlated with firm size, and managers always take decisions that will increase firm size even if it is not in the interests of shareholders. All these inclinations cause contradictions in the interests of both the managers and the shareholders, in that most often, managers prefer value expansion and owners desire maximisation of their share value. Several mechanisms have been institutionalised to solve these agency problems (conflict of interests) and the most influential among these is the use of managers' incentives (executive compensation). The aim of this incentive is to maintain goal congruence between the management and the owners by tying the wealth of the executives to the shareholders' wealth.

Executive compensation has for a long time attracted the attention of scholars in the area of financial economies. An in-depth study of the literature is still lacking, as executive compensation is viewed as a solution to agency problems but surprisingly it is one of the main products of agency problems that banks incur in monitoring and bonding costs, so as to ensure that compensation will not hinder the value of the bank (Bebchuk \& Fried, 2003). Numerous studies have been done on agency costs and executive compensation in the context of the banking and non-banking sector, to mention a few (see for example, Mohammed, 2013; Brockman \& Unlu, 2009; Chetty \& Saez, 2007; Shah \& Bhutta, 2013; Brau, 2002; Laiho, 2011; Neri, 2004; Manos, 2003; Claus \& Kim, 2004). Surprisingly, the attention of these researchers focused on the effect of ownership structure on agency costs, be it agency costs of debt or equity, and they viewed executive compensation as a remedy for agency problems neglecting the causes of agency costs, how they can be minimised in a firm, and the fact that executive compensation compounds the agency problem. For instance, managers may engage themselves via their compensation in empire building (Fama, 1980), and they can also divert the excess cash when the firm does not have profitable investment opportunities to their personal purse (Jensen \& Meckling, 1976). Also, managers may entrench themselves in the positions they occupy and owners find difficult to fire them whenever they fail to meet the target of the firm (Bebchuk \& Fried, 2003).

The question now is to what effect are the agency monitoring and bonding costs of banks on the compensation of managers since Jensen and Meckling (1976) affirmed that firms whose owners' wealth will be fully maximised must definitely incur monitoring and bonding costs. This is because the marginal benefits are always higher than the marginal costs. In the banking industry, there are some executive directors earning huge compensation despite the fact that the banks are not growing at the pace of their asset base. Managers find it interesting to incur bonding costs on behalf of the bank, because reducing agency costs will increase the bank value and this will cause a net increment in their wealth, which they consider more valuable than the perquisites they would have received. In Jensen's theory of the firm, bonding expenditure is assumed to attract the same rewards as the monitoring expenditure. Generally, it is more beneficial to the managers to incur these costs, even though it will reduce their pecuniary benefits, but in the long run, their gains from the increased value of the bank are always higher. This is because the cost function holding bonding and monitoring costs is such that the consequent benefit is always higher than the cost (Ang et al., 2000). In financial economics, the relationship between the agency problem and executive compensation can be approached in two ways: the optimal-contracting approach and the managerial-power approach. Under the first approach, Core, Guay and Larcker (2003) posit that managers are assumed to set up their compensation incentive in the sole interest of the shareholders and to maximise their wealth fully, hence, executive compensation is deemed as an instrument mitigating the agency problem in firms. But, the second approach, which is the main basis of this study, regards executive compensation not only as an instrument that can reduce the agency problem, but, as a major cause of the agency problem in companies, including in the banking industry.

Therefore, this study is unique and different from other studies by diverting attention from the ownership aspect of agency costs and digging deep into what makes up these costs, their roles in the managers executive compensation, and inquiring if these costs have been able to minimise the agency problem in South African 
banks having viewed executive compensation as one of the factors compounding the agency problem. In the course of our research, we have not found any such a study that has been done in the context of the banking industry, let alone on South African banks. Therefore, investigating the effect of agency monitoring and bonding costs on executive compensation in the banking context is ground-breaking in so far as the banking literature on the agency problem and costs is concerned.

\section{Literature Review}

Overview of South African Banking Industry: The financial services sector worldwide comprises banks, stock brokers, insurance companies, and pension funds with the primary assignment of rendering a wide range of services that enable job creation and the building of infrastructure, which leads to economic growth and sustainable development. According to a report on South African Reserve Bank (Ifeacho \& Ngalawa, 2014), the banking sector in South Africa represents over 50\% of the total assets of the entire financial sector, and the sector represents $20 \%$ of gross domestic product (GDP), with an asset base of over R6 trillion. The sector employs approximately $10 \%$ of the entire South African working population, and its tax payment contributes over $15 \%$ of GDP per year. The sector can be described as oligopolistic in nature with four largely-controlled banks, which have the largest market share of almost $82 \%$ of the total banking sector as at March 2014 (Standard-25\%, Almagated Bank of South Africa-20\%, First Rand Bank-20\%, Nedbank-17\% and others 18\%). The South African banking industry currently comprises 17 registered banks, 14 local branches of foreign banks, 2 mutual banks, 2 cooperative banks and 43 foreign banks operating under approved local representative offices. The South African banking sector is regulated and licensed under the Banking Act of 1990. It is a well-regulated sector whose operations are effectively overseen to maintain the global rating it has acquired. Due to this achievement, they operate under a range of Legislation that includes: the National Credit Act; the Competition Act; the Banking Act; the Financial Intelligence Centre Act (FICA); the National Payment System Act; the Financial Intermediary and Advisory Services Act (FAIS); the Home Loan and Mortgage Disclosure Act and the Consumer Protection Act, to mention a few. Also, South African banks have been mandated to comply with the Corporate Governance King Code practices, the newly concluded Basel III, and with ombudsmen tasked with instant and effective dispute resolution between institutions and their customers in an impartial, fair and confidential manner so as to ensure that maximisation of owners' wealth, which is their ultimate aim, is achieved.

This industry experienced a tier 2 banking crisis in 2002, due to the collapse of Saambou Bank which led to the closure of BOE bank and other smaller banks, which have not sought a renewal of their licences. Despite the effect of the 2007-2009 global economic crises, South Africa among all the countries in Sub-Saharan Africa (SSA) has a developed, globally competitive and well-regulated banking system in line with the banking sector in the industrialised countries. Even, the Banking Association of South Africa classified the sector as a very healthy sector. Although, over the past decade, the South African banking sector has been witnessing continuous change, it has attracted a lot of interest from overseas countries with respect to establishing foreign banks in the country, while the major banks have shares acquired by foreign shareholders. Recently in the 2013/2014 edition of the World Economic Forum Global Competitiveness Survey, the South African banking sector ranked third out of 148 countries. There have been a number of changes in policies guiding the banks, taking cognisance of the regulatory environment, product offerings, diversification into other financial activities aside from the traditional role, and an increase in financial deepening with the number of participants increasingly resulting in a greater competitive and stability level from smaller banks, which have targeted low-income citizens and reached out to the previously unbanked market. Figure 1 depicts the total assets of South African banks and their growth level, which calls for the attention to reducing agency costs which lead to exorbitant operating costs hindering their growth. Although they are growing, it is not at the same pace as their assets. Figure 1 depicts that the growth level is unstable and not moving at the same pace as the level of their assets. As at 2014, assets are at $8.2 \%$ and the growth rate is at $3.8 \%$. The gap between these two performance indicators is accounted for by the operational costs, which are relatively high, among many other factors, if not, they should be moving at the same pace. It is only in September 2011 that the growth level of the banks rose higher than the assets level to the tune of $8.2 \%$ to $6.7 \%$, which indicates the high efficiency level of South African banks in 2011. 
Figure 1: Schematic Diagram of Asset and Growth of South African Banks (2010-2014)

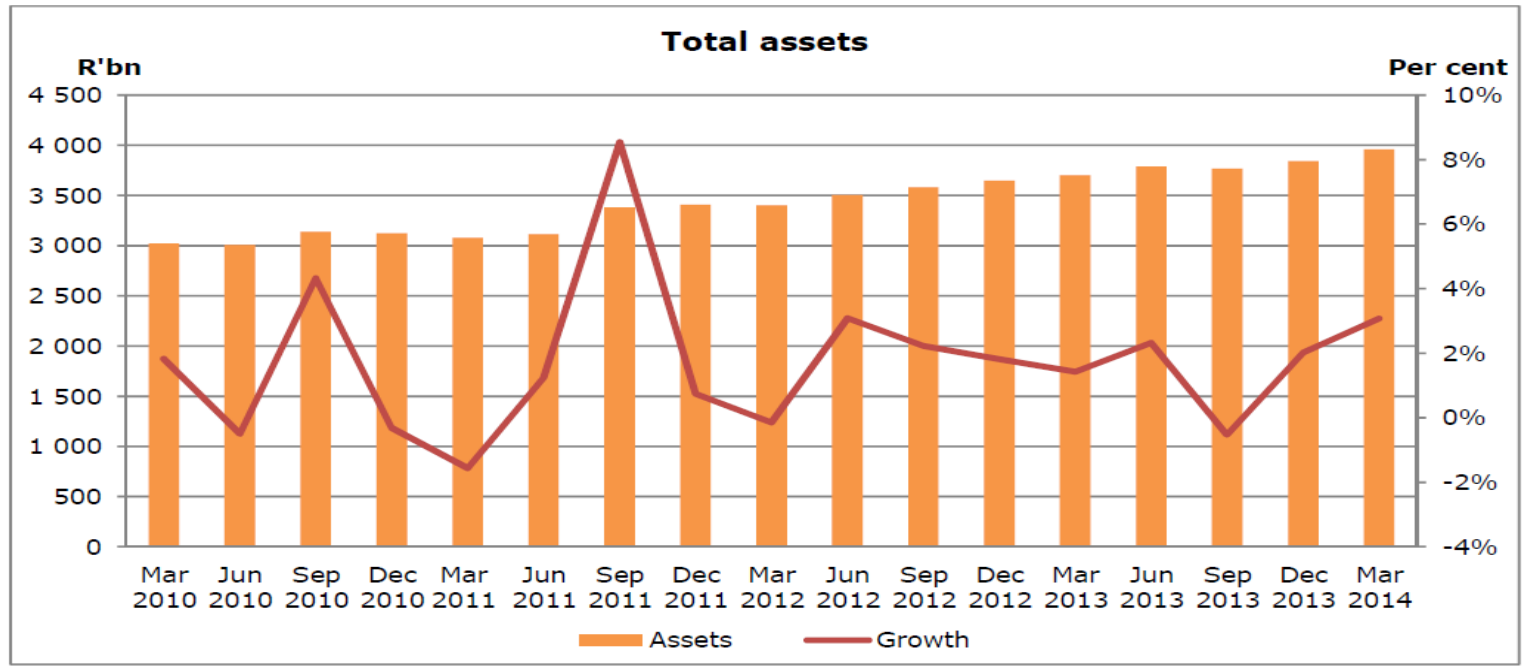

Source: SA Reserve Bank

Evidence from the annual reports and accounts of banks has shown that the highest proportion of banks' operational costs is the managers' executive compensation and pecuniary benefits, which is expected by the owners to minimise agency conflict that leads to agency problems. The agency monitoring and bonding costs incurred by shareholders and managers, respectively, so as to minimise the managers' benefit and considerably reduce the operating costs that hinders the growth of the banking industry. It was affirmed by the Banking Association of South Africa in 2011 that pressing issues hindering profitability and revenue generation which later have an adverse effect on the entire growth of banks in South Africa, are mainly due to increasing costs and economic conditions. Hence, it is expedient and of great interest to inquire into the effect of these costs on the managers' compensation (post-investment wealth) that comprises the greater proportion of banking operating costs causing disparity in the level of assets and growth due to the higher proportion of the South African banking sector's contribution to the economic growth of the country.

Theoretical Framework of the Study: This study is anchored on the principal- agent theory of firms. This was the first theory to open the black box of the firm as speculated by Adams Smith in $18^{\text {th }}$ century by conceptualising firms as a principal-agent relationship. According to this theory, frictions are bound to occur between owners of firms and the managers due to the asymmetric information between them, responsibility allocation and unending criticism of performances. Firms in an agency relationship whose ultimate aim is to maximise shareholders wealth must definitely have their principal incur monitoring costs and the agent incur bonding costs. It was affirmed by the theory that firms usually bear some costs due to agency problems inform of loss of potential gains and cost incurred to establish measures in order to reduce the loss of potential gains. It is combination of all these costs that this theory termed agency cost. Agency cost is the summation of monitoring costs, bonding costs and the residual loss, but the theory further explains that the residual loss is indirect and has no proxies in the report of firms, but it simply means the decrease in the firms' caused by the fact that they operate agency relationship. The theory of firm further states that firms stand to gain from incurring monitoring and bonding costs as the marginal benefit is always higher than the marginal cost (Jensen \& Meckling, 1976). Also, according to the theory, managers prefer shareholders to expend costs on monitoring their activities and they too find it interesting to expend bonding costs in order to increase the value of the firm. Although their fringe benefits may reduce, they prefer the rising value of the firm than the perquisites they get, as in the long run, they both benefit from the rising value of the firm.

\section{Methodology}

Due to the fact that this study is a quantitative study, it falls under the descriptive research design and positivism paradigm using the deductive approach. The major four commercial banks with almost $82 \%$ of South African total banking sector market share, namely, Standard Bank, ABSA, First Rand Bank (FRB) and 
Ned bank, are purposively used for this study for the period 2010 to 2015 due to the availability of their annual reports and accounts for the extraction of data. The variables of interest are sensitive data, which some other banks did not disclose in their annual reports and accounts. This study seeks to investigate the effect of agency bonding and monitoring costs in South African banks after the 2007-2009 global financial crisis as the trend of the growth of these banks since year 2010 has not been increasing proportionately with their huge asset base. Conducting the research till 2015 makes it an up-to-date study.

Data Sources: All the data used in this study are purely bank-specific in-depth data in either US dollars (USD) or ratio form. They are panel in nature. Panel data is considered suitable for this study because it gives a large number of data points that increases the degree of freedom and possibly decreases the co linearity problem among the regressors, and, hence, improves the efficiency of the econometrics estimates (Hsiao, 2003). The data were sourced from the annual reports and accounts of the banks accessible using the McGregor database, Bloomberg and the websites of some of the banks. Data in USD are naturally logged to enable the model to in the same base, and the annual data were converted to quarterly data so as to increase the frequency of the data, degree of freedom and enhance suitable regression analysis as posited by Armesto, Engemann and Owyang (2010) that conversion to produce higher frequency data generates no adverse effect but allows the standard regression technique to be explored. Thus, our data were averaged into quarterly data 2010 Q01 to $2015 \mathrm{Q} 04$.

Model Specification: Following the work of Jensen and Smith (2000) and Ang et al. (2000) Jensen and Meckling Model on the role of monitoring and bonding cost is adopted in this study. This model is used because of its distinct features such as:

- It is one of the most cited models in the finance papers; approximately 60,000 researchers have cited the model (Baiman, 1990; Schulze et al., 2001).

- Jensen and Meckling developed the agency theory of firms and pictured it mathematically in the agency cost model to suit diverse financial institution dimensions such as ownership structure, agency cost of debt and equity (Ang et al., 2000; Fama \& Jensen, 1983).

- It provides reasons for some firms not maximising owners' value and it is the model that is developed to set an optimal debt-equity mix which at the later end minimises total agency costs.

- Other theories such as Hill and Jones stakeholder-agency theory and the Barzel theory of firms referred back to Jensen and Meckling's agency theory and agency cost model.

The model:

Let $\alpha$ represents the proportion of owners' holding of shares and $1-\alpha$ be the proportion of owners' shares sold to the outsider where $0<\alpha<1$.

Let the payment made by the outsider for the $(1-\alpha)$ shares sold to them be represented by $R_{0}$ and the value of the owners' share of the firm on $\alpha$ proportion of shares is represented by $R_{1}$.

$R_{1}=\alpha V(F, \alpha)$

$R_{0}=(1-\alpha) V(F, \alpha)$

Where $V(F, \alpha)$ represents the value of the firm given that the insider value of share is $\alpha$ with managers perquisite market value of $F$.

The summation of equation $i$ and $i i$ is the owners' total wealth after selling $(1-\alpha)$ of the shares to outsiders, which is the shareholders fund for banks.

$R_{0}+R_{1}=Z$

$(1-\alpha) V(F, \alpha)+\alpha V(F, \alpha)=Z$.

$\mathrm{Z}$ represents the owners' total wealth after selling $(1-\alpha)$ of the shares to the outsider.

$F$ is the value of the perquisites managers received but it is expected to reduce as the firm incurs monitoring and bonding costs. That is, the highest level of perquisite managers can receive for different levels of monitoring and bonding costs is $F(M, B, \alpha)$. 
According to this theory, $V^{*}$ is the value of the firm when there is no expense on bonding and monitoring costs; and the insiders are the sole shareholders of the firm. It is a function of the value of investment $I$ and the current market value of the managers expenditure given a non-pecuniary benefit $F$.

$V^{*}=V(I, F)$

The total value of the firm for the sale of $(1-\alpha)$ of the total shares to the outsider is $V^{\prime}$ and the level of investment to outsiders is denoted by $I^{\prime}$ for instance, investment securities in a banking context.

Since the current value of the expected firm monitoring and bonding expenditures reduces the value of any given claim to the outside investors, the investors will take into consideration the monitoring and bonding costs in determining the maximum price they will pay for any further proportion of the firms' equity.

Therefore, the value of a firm given the fact that it incurs monitoring and bonding costs;

$$
V=\bar{V}-F(M, B, \alpha)-M-B \text {.. }
$$

Where $\bar{V}$ represents the value of the firm when the manager's expenditure on fringe non monetary benefits is zero $(0)$,

$M$ is the monitoring cost incurred by the shareholders and $B$ is the bonding cost incurred by the managers. The difference between the value of the shares totally owned by the firm and the value of the shares to the outsider is referred to as the managers' value of the shares, that is, the managers' option $\left(V^{*}-V^{\prime}=V^{\prime \prime}\right)$. Also the difference between the firms' total investment and the investment to outsiders is known as the managers' quota of investment $\left(I^{*}-I^{\prime}=I^{\prime \prime}\right)$.

Hence, the managers' post investment investment-financing wealth (compensation) is; $Z+V^{\prime \prime}-I^{\prime \prime}-M^{\prime \prime}-B^{\prime \prime}$ (vii)

In the context of the banking sector, the managers' post-investment-financing wealth is the managers' executive compensation or remuneration (EXC), $\mathrm{Z}$ is the total shareholders fund (SHF), $V^{\prime \prime}$ is the managers' share option (MOP), $I "$ is investment securities (INS), $M " a n d B "$ are the vectors of monitoring costs (MC) and bonding costs (BC) incurred on, and by the managers to ensure the agency cost of the bank is reduced. Therefore; $E X C^{\prime \prime}=Z+V^{\prime \prime}-I^{\prime \prime}-M^{\prime \prime}-B^{\prime \prime}$ (viii)

To write the model in an econometric form and to reflect a panel equation, stochastic error term $U_{i t}$, which is the proportion of variations in the managers' wealth that cannot be explained by the explanatory variables, is introduced:

$$
E X C_{i t}=\alpha_{0}+S H F_{i t}+M O P_{i t}-I N S_{i t}-\sum_{i=1}^{n} M C_{i t}-\sum_{i=1}^{n} B C_{i t}+U_{i t}
$$

Where, $\sum_{i=1}^{n} M C_{i t}$ is the summation of the monitoring cost incurred by shareholders [that is, audit fee (AUD), and leverage ratio of the bank (See Li \& Cui, 2003; Ang et al., 2000).

$\sum_{i=1}^{n} B C_{i t}$ is the summation of the of bonding cost incurred by the managers on behalf of the bank [i.e. licence and contractual guarantee fee (LGF), and dividend paid (DIV) (see Manos, 2003) Explicitly;

$$
E X C_{i t}=\alpha_{0}+\beta_{1} S H F_{i t}+\beta_{2} M O P_{i t}-\beta_{3} I N S_{i t}-\beta_{4} L E V_{i t}-\beta_{5} A U D_{i t}-\beta_{6} L G F_{i t}-\beta_{7} D I V_{i t}+U_{i t} . .(x)
$$

Hence,

$$
\begin{aligned}
& \ln E X C_{i t}=\alpha_{0}+\beta_{1} \ln S H F_{i t}+\beta_{2} \ln M O P_{i t}-\beta_{3} \ln I N S_{i t}-\beta_{4} L E V_{i t}-\beta_{5} \ln A U D_{i t}-\beta_{6} \ln L G F_{i t}
\end{aligned}
$$

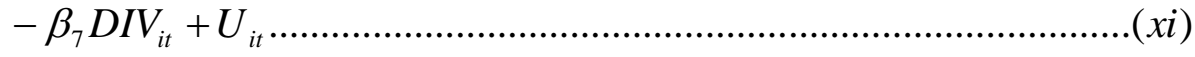


$\alpha_{0}$ is the constant introduced to the model and all variables are in logarithm form except LEV and DIV that are in their natural form.

$U_{i t}$ stands for the normal stochastic error term. It represents all other bank regulatory framework and market-related factors that randomly affect managers' compensation not captured by the explanatory variables over $t . U_{i t} \approx$ i.i.dN $\left(0, \sigma_{u}^{2}\right)$.

Variable Description: Where $\ln E X C_{i t}$ denotes the natural logarithm of the managers' remuneration. $\ln S H F_{i t}$ refers to the natural logarithm of the total shareholders' fund. $\ln M O P_{i t}$ is the natural logarithm of the total managements' share option. $\ln I N S_{i t}$ is the natural logarithm of the outsider share. $\ln A U D_{i t}$ refers to the natural logarithm of the auditors' fee and remuneration. $\ln L G F_{i t}$ stands for the natural logarithm of licence and contractual guarantee fees. $L E V_{i t}$ stands for the leverage ratio, which is expressed as $\frac{\text { Totaldebt }}{\text { Totalequity }} * 100 . D I V_{i t}$ stands for the dividend payment ratio by the bank. All variables across each bank $i$ over the years $t$.

A priori Expectation: According to Ang et al. (2000), Manos (2003), Li and Cui (2003), Khan et al. (2012) and Jensen's principal-agent theory of the firm, $\beta_{1} \& \beta_{2}>0$, while $\beta_{3}-\beta_{7}<0$. All these variables are expected to either increase or reduce managers' executive compensation and, hence, minimise agency problems affecting the value of the bank so that shareholders' wealth will be fully maximised irrespective of the policy adapted to either payout or to retain.

\section{Model Estimations and Data Analysis}

The model specified above is estimated using panel data estimation techniques. The use of panel data helps in increasing the sample size, increases the degrees of freedom significantly, reduces the presence of co linearity among the regressors, and hence, improves the efficiency of output derived from econometric estimates (Hsiao, 2005). This is of great impact in having a better understanding of the roles agency monitoring and bonding costs play on the managers' executive compensation in South African commercial banks. The pooled regression model, fixed effects model (FEM) and the Generalised Least Square (GLS) with weighted statistics are estimated.

\section{Why Pooled Ordinary Least Square, Fixed Effect Estimations and GLS?}

- According to Gujarati (2003), they are simple and preferable for large data sets because of their BLUE characteristic and the fact that they are computationally intractable.

- Fixed effect estimation cannot be biased because it controls for all the 'time-invariant' characteristics of each cross section (Torres-Reyna, 2007).

- GLS allows errors to be correlated and residual variances to differ.

\section{The general framework of the OLS model;}

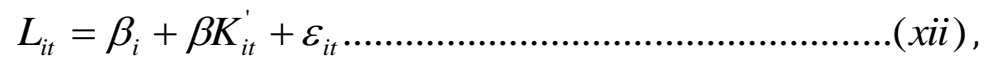

$K_{i t}^{\prime}$ is the vector of the explanatory variables. $i=1, \ldots \ldots \ldots \ldots \ldots \ldots, M . t=1, \ldots \ldots \ldots \ldots \ldots \ldots, N . d_{i}$ is the unobserved bank (cross-sectional) specific variable that is assumed to be constant over time.

Pooled Regression Model; $L_{i t}=\beta+\beta K_{i t}^{\prime}+\varepsilon_{i t}$ (xiii)

It is assumed that there is no unobserved individual heterogeneity, that is, $E\left(K_{t}, \varepsilon_{t}\right)=0$ for all time $t$ 
Fixed Effect Model; $L_{i t}=\beta_{i}+\beta K_{i t}^{\prime}+\varepsilon_{i t} \ldots \ldots \ldots \ldots \ldots \ldots \ldots \ldots \ldots \ldots \ldots . . .(x i v)$

FEM treats $\beta_{i}$ as a variable that is partially correlated with the observed independent variables and it solves the problems of omitted variable bias.

Generalised Least Square: The GLS model is a generalisation of OLS regression, which relaxes the assumption of ordinary least square that errors are uncorrelated and homoskedastic in nature. That is, OLS assumes that $\operatorname{Var}(\varepsilon)=\sigma^{2}$ I, while GLS assumes that $\operatorname{Var}(\varepsilon)=\sigma^{2} \Omega$. $\sigma^{2} \Omega$ is an $\mathrm{n} \times \mathrm{n}$ invertible and symmetric matrix whose off-diagonal elements show that errors are correlated for each pair of cases and whose elements that is diagonal in nature specify the error variances for each case. Privy to this change in underlying assumptions, GLS seems to be an unbiased estimator of $\beta$ rather than OLS with the minimum sampling variance among the class of linear unbiased estimators (Green \& Vavreck, 2008). According to Green and Vavreck (2008), the GLS estimator and its sampling variance are defined as:

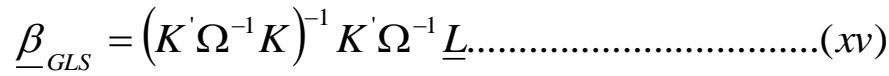

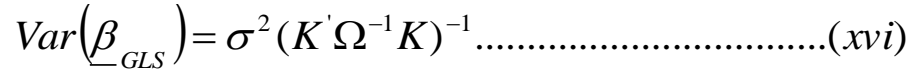

Descriptive Analysis: Descriptive statistics describe the basic characteristics of data, the summary statistics of the scale variables and various data measures of a large data set in a summarised table.

Table 1: Summary Statistics of the Series: EXC, SHF, MOP, INS, LEV, AUD, LGF, and DIV

\begin{tabular}{lllllllll}
\hline SERIES & EXC & SHF & MOP & INS & LEV & AUD & LGF & DIV \\
\hline Mean & 2.7740 & 5.0128 & 4.48534 & 3.6900 & 2.0815 & 2.8586 & 2.8338 & 1.5955 \\
Median & 2.7225 & 5.1186 & 4.50340 & 3.7676 & 2.4247 & 2.9592 & 2.8857 & 1.6130 \\
Max & 3.2178 & 5.6024 & 5.51943 & 4.3852 & 4.6454 & 3.4583 & 3.3991 & 2.1021 \\
Mini & 2.3163 & 3.9808 & 3.51023 & 2.8978 & 0.0881 & 1.9128 & 2.2799 & 1.0833 \\
Std-De & 0.2719 & 0.4727 & 0.43968 & 0.4927 & 0.9008 & 0.5102 & 0.3347 & 0.3011 \\
Skewn & 0.3492 & -0.7694 & 0.00414 & -0.4118 & -0.4006 & -0.7452 & -0.3173 & -0.0548 \\
Kurto & 1.7379 & 2.4379 & 2.93156 & 2.0505 & 2.5857 & 2.1650 & 1.9379 & 2.0042 \\
Jarq-B & 8.3233 & 10.735 & 0.01900 & 6.3191 & 3.2543 & 11.674 & 6.1227 & 4.0145 \\
Prob & 0.0156 & 0.0047 & 0.99054 & 0.0424 & 0.1965 & 0.0029 & 0.0468 & 0.1344 \\
Sum & 266.31 & 481.23 & 430.593 & 354.24 & 199.82 & 274.42 & 272.04 & 153.17 \\
Sum Sq. & 7.0232 & 21.226 & 18.3650 & 23.062 & 77.095 & 24.729 & 10.640 & 8.6139 \\
Obs. & 96 & 96 & 96 & 96 & 96 & 96 & 96 & 96
\end{tabular}

Source: Authors' Computation (2017) using E-Views 9.5 Statistical Package

The descriptive statistics of the variables as summarised in Table 1 show that all variables except executive compensation (EXC) and management share option (MOP) are positively skewed, indicating that they have a long right tail. However, from the statistics of kurtosis, it is depicted that the distribution of all the variables is flat relative to normal as their kurtosis is less than 3. The mean and median of the variables in the series falls within the maximum and minimum values. Moreover, the Jarque Bera statistics of most of the variables is greater than 5.99, except MOP, LEV and DIV, which indicates the acceptance of the null hypothesis of the model at $5 \%$ and, hence, there is evidence of normality in the model. Lastly, the probability value of most of the variables is less than $5 \%$, which indicates the model from the series will be of a good fit for the regression analysis.

Panel Ordinary Least Square: The estimation of pooled OLS places restrictions on the heterogeneity/uniqueness of the cross-sectional units with the assumption that both the constant/intercept estimates and the regression coefficient are unique for all cross sections (banks) over time. In other words, all the observations are stacked without giving consideration to the cross-sectional or time-specific features, and 
as such, the cross-sectional and time-related effects are ignored in the estimation. From the pooled LS result, investment securities, dividend paid and audit fee are statistically significant at $1 \%$ with only audit fee complying with the a priori expectation. MOP and LEV align with the a priori expectation but are not statistically significant. SHF and LEV are contrary to the a priori expectation but have an insignificant effect on managers' executive compensation in South African banks. The adjusted $\mathrm{R}^{2}$ of $85 \%$ shows that only a $15 \%$ variation in managers' executive compensation was not explained by the examined variables and the probability value of 0.000 shows the model has a line of best fit.

Table 2: Pooled and Fixed Effect Estimations of the Series: SHF, MOP, LGF, LEV, INS, DIV, AUD with Dependent Variable: MRE

\begin{tabular}{lllll}
\hline VARIABLES & $\begin{array}{l}\text { POOLED } \\
\text { COEFFICIENT }\end{array}$ & P-VALUE & $\begin{array}{l}\text { FEM } \\
\text { COEFFICIENT }\end{array}$ & P-VALUE \\
\hline C & 1.390740 & $0.0066^{* * *}$ & 13.42918 & $0.0000^{* * *}$ \\
SHF & -0.461588 & 0.2436 & -2.848677 & $0.0000^{* * *}$ \\
MOP & 0.062410 & 0.8299 & 1.579063 & $0.0001^{* * *}$ \\
LGF & -0.012814 & 0.8644 & 0.025146 & 0.6841 \\
LEV & 0.019591 & 0.7561 & 0.440453 & $0.0000^{* * *}$ \\
INS & 1.084996 & $0.0000^{* * *}$ & -1.329703 & $0.0110^{* * *}$ \\
DIV & 0.405433 & $0.0000^{* * *}$ & 2.291054 & $0.0000^{* * *}$ \\
AUD & -0.432996 & $0.0400^{* * *}$ & -1.117547 & $0.0000^{* * *}$ \\
R & $86 \%$ & & $92 \%$ & \\
ADJ R & $85 \%$ & & $91 \%$ & \\
PROB (F-STAT) & 0.000000 & & 0.000000 & \\
F-STAT & 78.84055 & & 94.43882 & \\
DW & 2.130446 & & 2.139754 & \\
\hline Source: Authors' Computation & & & \\
\hline
\end{tabular}

Source: Authors' Computation (2017) using E-Views 9.5 Statistical Package. Note that “***”, “**” and “*” represent $1 \%, 5 \%$, and $10 \%$ level of significance respectively.

Relative to the pooled regression estimator, the fixed effect estimator seems to be a better estimation in that it recognizes cross-sectional and/or time heterogeneity that may exist but is unobserved in the model. Thus, such a heterogeneity effect is incorporated in the model as an intercept term for each of the corresponding subject units and/or time period. From the FEM estimations, all the examined variables are statistically significant except the legal and guarantee fee (LGF), which is one of the components of agency-bonding costs that was insignificant but has a positive effect on managers' executive compensation contrary to the negative sign that we expect. Shareholders fund (SHF), outsider share (INS) and audit fee (AUD) have a negative effect on the managers' executive compensation, but it is only INS and AUD that aligns with the a priori expectation. The adjusted $\mathrm{R}^{2}$ of $91 \%$ shows only a $9 \%$ variation in EXC that is unexplained by the explanatory variables and, hence, catered for by the error term. The probability value of 0.000 shows the model has a line of best fit.

Panel Estimated Generalised Least Square: Table 3 shows the pooled and fixed effect GLS with the effect of cross-sectional weight. Our findings show from the pooled weighted estimations that all the variables examined are statistically significant at $1 \%, 5 \%$ and $10 \%$, respectively, except managers' options of share (insider shares), which is not significant but has a positive effect on managers' executive compensation. From the estimation, only MOP and LGF follow the a priori expectation while others variables negates our expectations. The probability value of 0.0000 and adjusted $\mathrm{R}^{2}$ of $95 \%$ and $85 \%$ for weighted and un-weighted statistics, respectively, show that the overall regression model is statistically significant and the explanatory variables were able to explain the managers' executive compensation in South Africa banks. From the findings of fixed effect weighted estimation, only licence and guarantee fee (LGF) and outsiders' shares (INS) are insignificant while other variables are statistically significant at $1 \%$. Also, we found that only managers' options (MOP), outsiders' shares (INS) and audit fee (AUD) align with the a priori expectation while others negate the a priori expectation. The probability value of 0.0000 shows the overall significance of the model 
with an adjusted $\mathrm{R}^{2}$ of $97 \%$ and $91 \%$ of weighted and un-weighted estimations of fixed effect, respectively, leaving $3 \%$ and $9 \%$ unexplainable executive compensation by the chosen variables for the stochastic error term.

Table 3: Cross Sectional Weight GLS of the Series: SHF, MOP, LGF, LEV, INS, DIV, AUD with Dependent Variable: MRE

\begin{tabular}{|c|c|c|c|c|}
\hline \multirow[t]{2}{*}{ VARIABLES } & \multicolumn{2}{|c|}{ POOLED-WEIGHTED } & \multicolumn{2}{|l|}{ FEM-WEIGHTED } \\
\hline & COEFFICIENT & P-VALUE & COEFFICIENT & P-VALUE \\
\hline $\mathrm{C}$ & 1.375250 & $0.0121^{* *}$ & 7.527835 & $0.0000^{* * *}$ \\
\hline SHF & -0.621727 & 0.0999* & -2.444891 & $0.0000^{* * *}$ \\
\hline MOP & 0.290966 & 0.1936 & 1.543855 & $0.0000^{* * *}$ \\
\hline LGF & -0.090016 & $0.0784^{*}$ & 0.023407 & 0.4435 \\
\hline LEV & 0.100111 & $0.0640^{*}$ & 0.423224 & $0.0000^{* * *}$ \\
\hline INS & 1.003438 & $0.0000^{* * *}$ & -0.202603 & 0.5025 \\
\hline DIV & 0.477016 & $0.0000^{* * *}$ & 1.471856 & $0.0000^{* * *}$ \\
\hline AUD & -0.419512 & $0.0353^{* *}$ & -0.689395 & $0.0041^{* * *}$ \\
\hline \multicolumn{5}{|c|}{ Weighted Statistics } \\
\hline $\mathrm{R}^{2}$ & \multicolumn{2}{|l|}{$95 \%$} & \multicolumn{2}{|l|}{$97 \%$} \\
\hline ADJ $R^{2}$ & \multicolumn{2}{|l|}{$94 \%$} & \multicolumn{2}{|l|}{$97 \%$} \\
\hline PROB (F-STAT) & \multicolumn{2}{|l|}{0.000000} & \multicolumn{2}{|l|}{0.000000} \\
\hline F-STAT & \multicolumn{2}{|l|}{218.2298} & \multicolumn{2}{|l|}{310.6181} \\
\hline \multicolumn{5}{|l|}{ SUM $^{2}$} \\
\hline RESIDUAL & \multicolumn{2}{|l|}{0.836622} & \multicolumn{2}{|l|}{0.453721} \\
\hline DW & \multicolumn{2}{|l|}{2.150703} & \multicolumn{2}{|l|}{2.162859} \\
\hline \multicolumn{5}{|c|}{ Unweighted Statistics } \\
\hline R2 & \multicolumn{2}{|c|}{$85 \%$} & \multicolumn{2}{|l|}{$91 \%$} \\
\hline \multirow{2}{*}{\multicolumn{2}{|c|}{$\begin{array}{l}\text { SUM }^{2} \text { RESIDUAL } \\
\text { DW }\end{array}$}} & & \multicolumn{2}{|l|}{0.654737} \\
\hline & & 2.112577 & \multicolumn{2}{|l|}{2.127714} \\
\hline
\end{tabular}

Source: Authors' Computation (2017) using E-Views 9.5 Statistical Package. Note that “***”, “**” and “*” represents $1 \%, 5 \%$, and $10 \%$ level of significance respectively

Redundant Fixed Effect Test: When the fixed effect model is considered, the OLS estimation becomes biased and has inconsistent estimates of the parameters in the regression. This is due to an omission of germane variable bias because of the fact that the pooled OLS expunges the individual dummies albeit that they are relevant in the model. The significance of individual specific effects is tested using the F-statistics. Therefore, this section presents the summary of the test statistics carried out to validate the presence of heterogeneity among cross-sectional units and across the time period. F and chi-square tests are carried out to ascertain whether there is a significant difference between the differential intercept across cross-sections and time period. Also, to confirm if the restriction of the pooled OLS estimation is justified or otherwise using the following:

$$
F_{o b s}=\frac{\left(R_{U R(F E M)}^{2}-R_{R(\text { POOLED })}^{2}\right) /(N-1)}{\left(1-R_{U R(F E M)}^{2}\right) /(N T-N-K)} \cong F_{N, N(T-1)-K}
$$


Table 4: Restricted F-Statistics

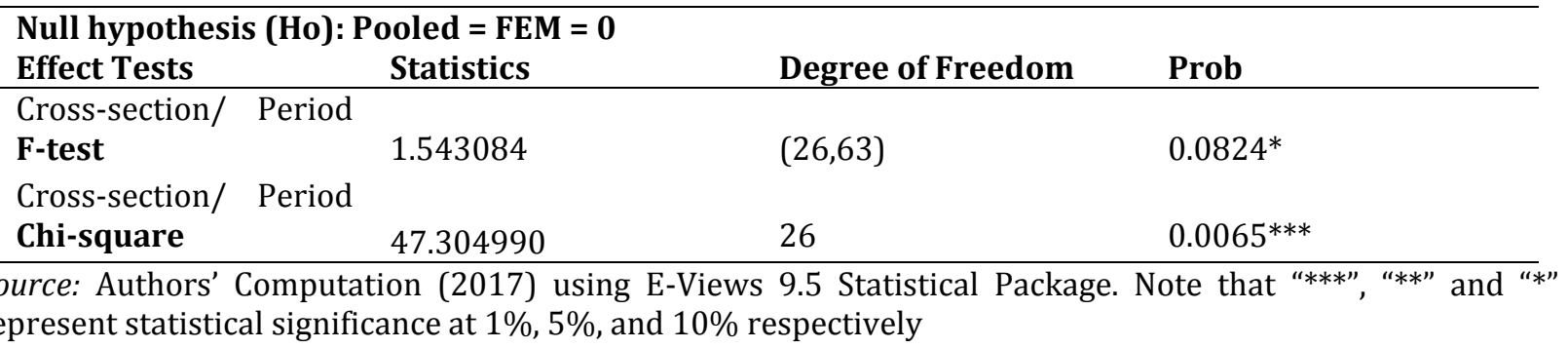

Table 4 shows that both the F-test and the chi-square test is significant at $10 \%$ and $1 \%$, respectively, which indicates the rejection of the null hypothesis (there is no significant difference between the pooled estimation and the fixed effect estimation) and concludes that there is a significant difference between the pooled and FE estimations. Hence, our conclusion in this study is based on the FEM estimations.

Implication of Findings: From the restricted test of fixed effect, it was concluded that our implication of findings is based on the fixed effect estimation, but due to the fact that the GLS relaxes the assumption of ordinary least square that errors are uncorrelated and homoskedastic in nature, the GLS fixed effect estimations form the basis of our discussion. According to Green and Vavreck (2008), GLS estimations are unbiased estimations rather than the OLS with a relatively small sampling variance compared to other linear unbiased estimators. Hence, this study bases the discussion of the findings on the fixed effect estimated GLS with weighted and un-weighted statistics. The negative and significant effect of the shareholders' fund implies that being a common financial metrics used by analysts to determine the health of a bank, an increase in this fund leads to a decrease in the executive compensation, which means that instead of paying exorbitant fees for the managers the owners will invest the fund in positive and viable Net Present Value (NPV) projects and explore all other opportunities for expanding the scope of the bank as a bank with a higher SHF will be big enough to devise other means of compensating their managers whether in terms of shares, which will keep on increasing the asset base of the bank or other flexible pecuniary rewards that will not compound the agency costs leading to higher operating costs hindering their growth.

Also managers' option of shares (MOP) has a positive effect as expected. The management team also has a percentage of insider shares in the bank as most of them are part of the bank's board of directors. Logically, the higher their shareholdings, the more compensation they allocate to themselves from the banks' earnings. As it has been concluded by Rozeff (1982) that agency costs can be minimised via a dividend payout policy and debt ratio (leverage), managers executive compensation is expect to reduce by an increase in the leverage ratio, dividend payout ratio and audit fees incurred by the managers being the components of monitoring and bonding costs. Our findings on SSA banks show that a percentage increase in leverage and dividend payout ratios leads to $42 \%$ and $147 \%$ increase in managers' executive compensation. This increase could be traced to the fact that the higher debt commitment a bank commits itself to, the higher the compensation paid to the management team to be able to expedite activities that will not default the terms and conditions of the debt, thus, it compounds the agency problem (costs) in the bank. Also, a $1 \%$ increase in audit fees (AUD) which is one of the components of agency bonding costs will lead to a $68 \%$ reduction in managers' executive compensation as expected, hence, South African banks should keep on subjecting their annual reports to external examination by an independent auditor as it is a good bonding cost to minimise agency problems emanating from exorbitant executive compensation. Lastly, outsiders shares (INS) and the legal and guarantee fee (LGF) have no significant effect on managers' executive compensation in South African banks with outsiders shares causing a 20\% decrease and LGF posing a $2 \%$ increase. The findings on the leverage ratio oppose the findings of Nazir and Saita (2013) but conform to the findings of Ang et al. (2000), and the positive and significant dividend ratio conform to the study of Khan et al. (2013). Conclusively, our findings on South African banking sector's managers' executive, and agency costs model is stated as:

$E X C=-2.44 S H F+1.54 M O P+0.02 L G F+0.42 L E V-0.20 I N S+1.47 D I V-0.69 A U D$. 


\section{Conclusion and Recommendations}

Premised on our findings, we conclude that: firstly, the dividend payout policy, which is expected to be a bonding measure on managers, does not mitigate managers' executive compensation which constitutes the larger proportion of the agency cost banks incur; hence, other dividend policies can be explored. Secondly, banks in South Africa should keep on subjecting their annual reports and accounts to external auditing as it is a significant factor mitigating the agency costs by enabling the managers to bond themselves to always protect the owners' interests as all hiding activities will be revealed via the auditing process. Thirdly, the banking sector shareholders should not be carried away by the agency relationship in establishing the relationship between the executive compensation and agency problem. For the banking sector, the managerial-power approach should be embarked upon and not the optimal-contracting approach of agency cost, due to the fact that managers are found to always pursue their interest in all their decisions at the expense of the owners of the bank. Moreover, from our findings, banks' leverage does not reduce managers' executive compensation; therefore, banks should curtail their debt level even though the marginal benefits might be greater than the marginal costs. Lastly the major factors that have a significant effect on managers' executive compensation in South African banks are shareholders' funds, the management shares' option, the leverage ratio, dividend payout ratio and audit fees paid by the banks; thus the need to give considerable attention to these factors so that the agency costs of banks causing disparity in their asset level and growth rate will be minimised.

Suggestions for Further Research: Our study is not without limitation; hence, further research should extend the period of this study and more so, examine other factors such as the board of directors' composition and inquire about their effect on managers' compensation (post-investment-financing wealth). Also, agency costs apply to all the firms operating an agency relationship and not only in the banking sector. Would-be researchers can conduct this same study on these other sectors and expand the literature on agency costs, to compare how these factors respond to executive compensation across various sectors of the economy to enhance adequate comparison.

\section{References}

Ang, J. S., Cole, R. A. \& Lin, J. W. (2000). Agency costs and ownership structure. Journal of Finance, 55(1), 81106.

Armesto, M. T., Engemann, K. M. \& Owyang, M. T. (2010). Forecasting with mixed frequencies. Review, 92(1), $1-25$.

Baiman, S. (1990). Agency research in managerial accounting: A second look. Accounting, Organizations and Society, 15(4), 341-371.

Bebchuk, L. \& Fried, J. (2003). Executive compensation as an agency problem. Journal of Economic Perspectives, 17(3), 71-92.

Brau, J. C. (2002). Do banks price owner-manager agency costs? An examination of small business borrowing. Journal of Small Business Management, 40(4), 273-286.

Brockman, P. \& Unlu, E. (2009). Dividend policy, creditor rights, and the agency costs of debt. Journal of Financial Economics, 92(2), 276-299.

Chetty, R. \& Saez, E. (2007). An agency theory of dividend taxation (No. w13538). National Bureau of Economic Research.

Claus, I. \& Kim O. (2004). Agency costs, asymmetric information and financial intermediation in a small open economy. In New Zealand Association of Economists Conference.

Collier, P. M. \& Agyei-Ampomah, S. (2006). Management Accounting-Risk and Control Strategy: Paper P3. CIMA Learning Systems Strategic Level 2007. Elsevier Science \& Technology.

Core, J. E., Guay, W. R. \& Larcker, D. F. (2003). Executive equity compensation and incentives: A survey. Economic Policy review, 9(1).

Fama, E. F. (1980). Agency problems and the theory of the Firm. The Journal of Political Economy, 5(1), 288307.

Fama, E. F. \& Jensen, M. C. (1983). Separation of ownership and control. The journal of law and Economics, 26(2), 301-325. 
Green, D. P. \& Vavreck, L. (2008). Analysis of cluster-randomized experiments: A comparison of alternative estimation approaches. Political Analysis, 16(2), 138-152.

Gujarati, D. N. (2003). Basic Econometrics. $4^{\text {th }}$ ed. New York: McGraw-Hill.

Hsiao, C. (2005). Why panel data? The Singapore Economic Review, 50(02), 143-154.

Ifeacho, C. \& Ngalawa, H. (2014). Performance of The South African Banking Sector Since 1994. Journal of Applied Business Research, 30(4), 1183-1195.

Jensen, M. C. \& Meckling, W. H. (1976). Theory of the firm: Managerial behavior, agency costs and ownership structure. Journal of Financial Economics, 3(4), 305-360.

Jensen, M. C. \& Smith, C. W. (2000). Stockholder, manager, and creditor interests: Applications of agency theory. Theory of the Firm, 1(1).

Kantarelis, D. (2007). Theories of the firm. Inderscience Genève Switzerland

Khan, A., Kaleem, A. \& Nazir, M. S. (2012). Impact of financial leverage on agency cost of free cash flow: Evidence from the manufacturing sector of Pakistan. Journal of Basic and Applied Scientific Research, 2(7), 6694-6700.

Laiho, T. (2011). Agency theory and ownership structure-Estimating the effect of ownership structure on firm performance.

Li, H. \& Cui, L. (2003). Empirical study of capital structure on agency costs in Chinese listed firms. Nature and science, $1(1), 12-20$.

Manos, R. (2003). Dividend policy and agency theory: Evidence from Indian firms. South Asia Economic Journal, 4(2), 275-300.

Masulis, R. W. \& Trueman, B. (1988). Corporate investment and dividend decisions under differential personal taxation. Journal of Financial and Quantitative Analysis, 23(04), 369-385.

Mehran, H. (1995). Executive compensation structure, ownership, and firm performance. Journal of financial economics, 38(2), 163-184.

Mohammed, D. (2013). A dynamic panel model of capital structure and agency cost in Nigerian listed companies. Global Journal of Business Research, 5(2), 33-44.

Murphy, K. J. (1985). Corporate performance and managerial remuneration: An empirical analysis. Journal of Accounting and Economics, 7(1), 11-42.

Nazir, S. \& Saita, H. K. (2013). Financial Leverage and Agency Cost: An Empirical Evidence of Pakistan. Int. Journal of Innovative and Applied Finance-IJIAF, 1(1).

Neri, S. (2004). Agency costs or costly capital adjustment DSGE models? A Bayesian investigation. Manuscript, Bank of Italy.

Rozeff, M. S. (1982). Growth, beta and agency costs as determinants of dividend payout ratios. Journal of Financial Research, 5(3), 249-259.

Schulze, W. S., Lubatkin, M. H., Dino, R. N. \& Buchholtz, A. K. (2001). Agency relationships in family firms: Theory and evidence. Organization science, 12(2), 99-116.

Shah, S. Z. A. \& Bhutta, N. T. (2013). Corporate Entrepreneurship and Agency Cost: A Theoretical Perspective.

Shleifer, A. \& Vishny, R. W. (1989). Management entrenchment: The case of manager-specific investments. Journal of financial economics, 25(1), 123-139.

Torres-Reyna, O. (2007). Panel data analysis fixed and random affects using Stata (v. 4.2). Data \& Statistical Services, Priceton University. 